\title{
Replacing Local Labors Instead of Expatriate in Jordan Tourism Sector
}

\author{
Ehab Abdul Raheem Alshatnawi \\ Travel and Tourism Management, Faculty of Tourism and Hospitality, \\ University of Jordan, Amman, Jordan
}

doi: 10.19044/esj.2016.v12n11p553 URL:http://dx.doi.org/10.19044/esj.2016.v12n11p553

\begin{abstract}
The objective of this current study is to identify the issue of tourist expatriate labor, its effects on the touristic and economic levels, its ways of evaluation, the manner of dealing with its reasons and motivations, and the ways of replacing it with local labor. However, this labor is able to fill the gap to and from a pure Jordanian touristic product. In addition, it is able to obtain the maximum benefit from tourist activity. The results of the study revealed that the expatriate labor represents $17.6 \%$ of the total labor in the Jordanian tourist sector. Therefore, most of these labors are concentrated in hotels and tourist restaurants. Tourism is one of the Jordanian sectors that do not attract local labor, but are attractive to expatriate labor. The expatriate labor in the Jordanian tourist sector is complementary. Hence, it is not a substitute for the tourist professions. The study recommended the need to develop local tourist workers by holding courses for the Jordanian workers in the tourist hotels and restaurants. Also, training on lingual and specialized tasks which focuses on the medium university education should be provided for them. Also, vocational training corporations should be organized. This in turn fills the gap of the tourist activities that attract expatriate labor and amendment legislation and laws relating to wages and the nature of work in the tourism sector. Hence, this is aimed to attract local tourist labor.
\end{abstract}

Keywords: Tourist Labor, Local Tourist Labor, Expatriate Labor, Replace Labor

\section{Introduction}

Considering the role of tourism in extensive development, many countries, especially the developing ones, have chosen this industry to be the corner stone of their national economy. Thus, an example of these countries is Jordan. 
Tourism in Jordan is the greatest and fastest growing and developing industry in view of its various components and the ability of this sector. Thus, this sector has international competitiveness in terms of the invested capital, foreign currency revenues sector, and the number of workers in this field (Al-Etoum, 2003).

Therefore, Jordan, like other developing countries, depends on tourism as a basic resource of national income. Also, it exerts all possible efforts to provide the requirements of this industry. This is done by finding the necessary balances to achieve influential tourism that positively affects national economy to raise the per capita income and the standard of living.

This research sheds light on the issue of tourist expatriate labor, its effects on the touristic and economic levels, its ways of evaluation, the manner of dealing with its reasons and motivations, and ways of replacing it with local labor. However, this labor is able to fill the gap to and from a pure Jordanian touristic product. In addition, it is able to obtain the maximum benefit from tourist activity.

Consequently, this research contains two chapters. The first chapter handles expatriate labor in Jordan in general and in the tourist sector in particular. Thus, this is in addition to analyzing its statistics, reasons, and features. On the other hand, the second and last chapter offers an exploratory study, tests, and analyzes of the hypotheses to present results and recommendations.

\section{The Problem of the Study}

In spite of the notable growth and development of Jordanian tourism and the realization of most of its plans and strategic objectives, the tourism sector in Jordan is still the greatest attractive sectors for expatriate labor in terms of quantity and diversity. The number of foreign workers in the Jordanian tourism sector in 2015 counted 8.475 and rated $17.6 \%$ of the workers in tourism. Thus, this statistics was provided by Tourism and Antiquities Ministry in Jordan (2016).

Furthermore, this negatively reflects on the main goals of tourism in providing job opportunities and distributing income. The problem of the study can be presented in the following questions:

1- What are the characteristics and attributes of the tourism expatriate labor in Jordan?

2- What are the limitations of the Jordanian labor in the sector of tourism?

3- What is the impact of the tourist expatriate labor on the Jordanian tourism sector? 


\section{The Importance of the Study}

The significance of this study springs out from the importance of tourism and its main goals. This can be seen based on its contribution to the national income, provision of hard currencies, and the creation of job opportunities.

The importance of this study also follows the prominence of realizing the Maximus benefit from tourist activities. It also maintains the returns and products of tourism sector within the Jordanian lands.

\section{The objectives of the Study}

This study aims to perform the following objectives:

1- To highlight the reality of the expatriate tourism labor in Jordan, its characteristics, and the provisions of employment.

2- To determine the nature of the obstacles and limitations that prevents the Jordanian labor from working in the tourist sector which necessitates bringing them from abroad.

3- To work on creating a database that may help in finding the Jordanian labor which could cover the requirements of the tourist sector.

4- To present a number of recommendations that contributes in drawing the administrative and technical solutions to replace the expatriate labor with Jordanian labor in the Jordanian tourist sector.

5- To serve as an inducement in conducting more studies and reports concerning the Jordanian and expatriate labor in the Jordanian tourist sector.

\section{The Hypotheses}

- There is positive relationship between the characteristics and specifications of the expatriate labor and their work in the Jordanian tourist sector.

- There is a positive relationship between tourist work environment and the employment of expatriate labor in the Jordanian tourist sector.

\section{Previous Studies}

Several studies have examined expatriate labor and how it can be replaced with local labor. However, few of these studies have attempted to examine expatriate labor and how to replace it with local labor in the tourism sector. These few studies are as follows:

Osama Adnan Alffendi \& Alaa Ghalib Albashaireh (2014)

This study mainly aims to compare the economic, social, and demographic characteristics of local labor and foreign labor. This is with the aim of reaching a classification for foreign labor that helps decision-makers to reduce unemployment. The study concluded that the vast majority of foreign labor was young workers. Thus, they were unemployed Jordanians slice and are more youthful. 

(2012)

Farouq Al Azzam, Qusay Qahtan Khaleefah, \& Omar A A Jawabreh

This study aims at indicating the right foundations that may be adopted by departments of foreign managers about their employees and the possibility of employment of those grounds. This is in support of the local section managers to manage the partitions in the four and five star hotels in Aqaba. The study concluded that there is no difference between foreign and local managers in managing the operational departments of hotels in the study sample.

Abdel Baset Athamneh (2011)

This study aimed at estimating the productivity of both Jordanian labor and the guest labor inside Jordan. It also considers the possibility of substituting foreigners with Jordanians in the labor market. The results of the study showed significant difficulties in substituting the guest labor like that which was available before. This is because its productivity began after 1995, and is higher than that of Jordanians. The study recommended an increase in the minimum wage level, continuation in raising the cost of guest labor, and the supporting of the export sector by employing Jordanians.

Furthermore, Dunning \& Lundan (2008) conducted a study about the quality of hospitality in five star hotels under a management of foreign managers. This study showed the positive impact of foreign managers on the hotels and the quality of their services. It also shows the significance of using foreign managers to improve the performance of local managers. However, this is because local managers will gain new knowledge and experience from them.

Te Velde \& Morrissey (2002) conducted a study named "Sustainable Development of The Tourism Industry in South Africa and Consequences of Foreign Management on Local Employees.” This study was done in South Africa and it targeted the high standards of hospitality services there. In addition, it encouraged the local employees to be trained by foreign managers so that they can learn from them. In the study, local employees benefitted from the foreign managers and gained a lot of experience. In addition, this study revealed the degree of the quality of services in the hotels that was developed and further improved.

Ashley \& Roe (2002) conducted a study in Kenya and Tanzania about employing foreign administers and mangers. They further describe how they transfer their knowledge to the local administers and mangers. This study showed that over time, the foreign administers and mangers were replaced by local administers and mangers. This is based on the fact that they were ready to handle and manage those positions just like the foreign administers and mangers. Subsequently, this also made hotels to save more money since they are no longer paying administers and mangers high wages. 


\section{The Tourist Expatriate Labor and How to replace it with Local Tourist Labor}

Tourism is one of the relatively new sectors in Jordan. However, despite the novelty of this sector, it jutted strongly as an important economic resource in the Kingdom. The Jordanian tourist product, with its components, was able to attract many internal and external investments which have helped in the growth and development of this industry. It has also facilitated the opening of the sphere for the Jordanian society members to get involved in the Jordanian tourism.

The Jordanian tourist market is characterized by the huge employment of males on account of females. Thus, this could be attributed to several factors which include the social discipline and the societal engagements of a female in the Jordanian society.

Table 1. Shows the number and categorization of the workers in the Jordanian tourist market according to gender

\begin{tabular}{|l|l|l|l|}
\hline \multirow{2}{*}{ Year } & Gender & \multirow{2}{*}{ Relative Weight \% for Female } \\
\cline { 2 - 3 } & Male & Female & $10.5 \%$ \\
\hline 2011 & 37,488 & 4,391 & $10 \%$ \\
\hline 2012 & 39,460 & 4,482 & $10 \%$ \\
\hline 2013 & 43,408 & 4,743 & $10 \%$ \\
\hline 2014 & 44,008 & 4,657 & $10 \%$ \\
\hline 2015 & 43,485 & 4,772 & \\
\hline
\end{tabular}

Prepared by researcher

Source: Ministry of Tourism \& Antiquities, 2015

It is clear from the table that the ratio of female workers is little compared to males. The fixed ratio is also clear for the said years. Despite its expansion and growth, the tourist sector is still attracting the expatriate labor increasingly during the recent years as shown in table 2.

Table 2. The number of workers in the tourist sector from 2011 to 2015

\begin{tabular}{|c|c|c|c|c|c|c|c|c|c|c|}
\hline \multirow{2}{*}{ Item } & \multicolumn{2}{|r|}{2011} & \multicolumn{2}{|r|}{2012} & \multicolumn{2}{|r|}{2013} & \multicolumn{2}{|r|}{2014} & \multicolumn{2}{|r|}{2015} \\
\hline & Jordanian & \begin{tabular}{|l|} 
Non \\
Jordanian \\
\end{tabular} & Jordanian & $\begin{array}{l}\text { Non } \\
\text { Jordanian } \\
\end{array}$ & Jordanian & \begin{tabular}{|l|} 
Non \\
Jordanian \\
\end{tabular} & Jordanian & \begin{tabular}{|l|} 
Non \\
Jordanian \\
\end{tabular} & Jordanian & $\begin{array}{l}\text { Non } \\
\text { Jordanian } \\
\end{array}$ \\
\hline Hotels & 13,259 & 1,915 & 13,460 & 1,959 & 16,226 & 2,081 & 16,535 & 2,109 & 16,555 & 2,118 \\
\hline Travel Agencies & 4,434 & 148 & 4,560 & 159 & 4,602 & 181 & 4,870 & 101 & 4,993 & 116 \\
\hline $\begin{array}{lll}\text { Rent a } & \text { Car } \\
\text { Offices } & \\
\end{array}$ & 1,473 & 16 & 1,473 & 16 & 1,460 & 16 & 1,460 & 16 & 1,460 & 16 \\
\hline Horses Guides & 713 & & 713 & & 713 & & 713 & & 713 & \\
\hline $\begin{array}{l}\text { Tourist } \\
\text { Transpor.Comp. }\end{array}$ & 906 & 33 & 906 & 33 & 1,000 & 47 & 1,000 & 47 & 1,000 & 47 \\
\hline Diving Centers & 34 & 14 & 34 & 14 & 34 & 14 & 34 & 14 & 34 & 14 \\
\hline Water Sports & 119 & 6 & 119 & 6 & 119 & 6 & 119 & 6 & 119 & 6 \\
\hline Total & 33,841 & 8,038 & 35,311 & 8,631 & 39,366 & 8,785 & 40,105 & 8,560 & 39,782 & 8,475 \\
\hline
\end{tabular}


Table 3 reveals that the overall tourist labor, whether the expatriate or local, is stationed at hotel facilities. Therefore, this could be attributed to the diversity of their divisions and the variety of services that require big number of workers.

This is followed by tourist restaurants because of the multiplicity of those restaurants that need some numbers of workers in each division (the main hall, the kitchen). It also requires different specializations for food and drink in order to meet the needs and desires of customers.

On the second level, we find a collection of tourist activities that incorporate a large number of employees like travel agencies, tourist guides, tourist transportation companies, and water events. However, this level is in a less volume than hotels and restaurants as shown in table 3.

Table 3. The number of expats in tourist hotels and restaurants in comparison with the overall labor in 2015

\begin{tabular}{|l|l|l|l|l|}
\hline \multirow{2}{*}{ Item } & \multicolumn{3}{|c|}{ Nationality } \\
\cline { 2 - 5 } & Jordanian & $\begin{array}{l}\text { Non } \\
\text { Jordanian }\end{array}$ & Total & $\begin{array}{l}\text { Percentage of Foreign Workers } \\
\text { to the Total }\end{array}$ \\
\hline Hotels & 16,555 & 2,118 & $\mathbf{1 8 , 6 7 3}$ & $11.3 \%$ \\
\hline $\begin{array}{l}\text { Tourism } \\
\text { Restaurants }\end{array}$ & 12,756 & 6,117 & $\mathbf{1 8 , 8 7 3}$ & $32.4 \%$ \\
\hline
\end{tabular}

Prepared by researcher

Source: Ministry of Tourism \& Antiquities, 2015

\section{Methodology of the Study}

To achieve its objectives, the study relied on the desk and field styles by following the descriptive analytical approach. In this approach, the researcher collects information, researches, studies, publications, and statistics that are related to the theme of the research.

As for the field side, the researcher will follow three methods in the preliminary data. Firstly, a questionnaire that consists of (28) questions is distributed on Likert Scale quintet for the expatriate and Jordanian workers in hotels and restaurants. Secondly, personal interviews were conducted to collect data in the domain of the personnel managers in tourist hotels and restaurants. Thirdly, observation will be used to determine some data during filed roaming in order to specify results and infer conclusions.

\section{The Research Population and Sample}

The research population consists of all the expatriate workers in the tourist hotels and restaurants in Jordan. Table 3 shows the number of expats in those activities in 2015.

Examining the above stated table, we find that the percentage of expatriate workers in tourist hotels is $11.3 \%$, while it is $32.4 \%$ in tourist restaurants. The researcher chose the tourist hotels and restaurants because 
the expatriate labor is concentrated on them compared with the other Jordanian tourist activities.

Based on the study objectives, a random purposive sample of 250 Jordanian and expatriate workers was selected. The sample was divided on the study variables (gender, age, social status, educational level, tourist activity). 233 analyzable questionnaires, at the rate of $93 \%$ of the sample members, were retrieved.

Furthermore, the researcher conducted an exploratory study that included personnel managers and employment officers in four hotels and six tourist restaurants. Thus, this is aimed in determining the aspects and dimensions of the study.

\section{General Indicators of the Sample}

As was formerly mentioned, the study variables were divided into five parts. These parts are namely: gender of two types (male, female), social status as a second variable of three types (single, married, others), the third part age of six types (20 and less, 21-30 , 31-40, 41-50, 51-60, over 60), the fourth part of the educational level of four types (general secondary and less, middle diploma, bachelor's degree, higher studies), and the fifth and last part which is tourist activity of two types (hotel, tourist restaurant).

However, the researcher used those variables because of their close connection to the subject matter of the research. In gender variable, the researcher expects the answers of the sample members to be affected by gender, and the desire and ability to work in the tourist sector. Thus, this is selected according to their gender.

As for social status, it is a determination of the nature of the employees and the capacity of tourist work to meet the living requirements of the worker and his family. Hence, this could be the motive behind working in the tourist sector.

Concerning age, the researcher expects the responses of the sample to be affected by the age group and the desire and motivation to work in the tourist sector.

Regarding the fourth variable which is the educational level, the researcher depended on this variable because he expects the responses of the sample members to vary in pursuant to this variable. This is especially concerning the connection to the ability of the respondent, to knowledge, and to the advantage of working in the tourism sector. In addition, it considers the ability of the sector to incorporate trained and qualified labor.

As for the fifth and last variable, the researcher sees that the responses of the sample members may differ from this variable. Thus, this is especially because of the different nature of work in both of them. It also constitutes the difference in the work requirements and conditions. 
Consequently, the questionnaire also contained some general indicators of the study sample such as job title, the division or department in which the employee works, years of experience, and foreign languages. This as a whole represents a general outlook at the characteristics of expatriate labor in Jordan as was clarified in table 4.

Table 4. Explains the distribution of the sample members on the study variables and their

\begin{tabular}{|c|c|c|c|}
\hline Variable & Types of variables & Number & Percentage \\
\hline \multirow[b]{2}{*}{ Nationality } & Jordanian & 112 & $\% 48.1$ \\
\hline & Expat & 121 & $\% 51.9$ \\
\hline & Total & 233 & $\% 100$ \\
\hline \multirow[b]{2}{*}{ Gender } & Male & 199 & $\% .81 .5$ \\
\hline & Female & 34 & $\% 18.5$ \\
\hline & Total & 233 & $\% 100$ \\
\hline \multirow{6}{*}{ Age } & 20 and less & 10 & $\% 4.3$ \\
\hline & $21-30$ & 169 & $\% 72.5$ \\
\hline & $31-40$ & 49 & $\% 21$ \\
\hline & $41-50$ & 5 & $\% 2.2$ \\
\hline & $51-60$ & - & $\% 0$ \\
\hline & 60 and more & - & $\% 0$ \\
\hline & Total & 233 & $\% 100$ \\
\hline \multirow[b]{4}{*}{ Educational level } & $\begin{array}{ll}\text { General secondary } \\
\text { and less }\end{array}$ & 98 & $\% 42.1$ \\
\hline & Middle diploma & 99 & $\% 42.5$ \\
\hline & Bachelor's degree & 36 & $\% 15.4$ \\
\hline & Higher Studies & - & $\% 0$ \\
\hline & Total & 233 & $\% 100$ \\
\hline \multirow{3}{*}{ Tourist activity } & Hotel & 153 & $\% 65.7$ \\
\hline & Tourist Restaurant & 80 & $\% 34.3$ \\
\hline & Total & 233 & $\% 100$ \\
\hline
\end{tabular}

Through a close look at the nature and properties of the sample and its division, we find that the proportion of the Jordanians formed $48.1 \%$ of the total number of the sample, and $0.005 \%$ of the total Jordanian workers in hotels and restaurants. On the other hand, the expatriate labor constituted 
$51.9 \%$ of the sample and $0.009 \%$ of the total expatriate workers in the Jordanian hotels and tourist restaurants.

As for gender, the ratio of males was $85.4 \%$, while that of females was $14.6 \%$. Therefore, the reason could be that males are more capable and appropriate to work in hotels and restaurants than females. The ratio is near to the percentage of females who work in the Jordanian tourist sector, in general, as it reached $10 \%$ of the overall tourist sector's workers.

Coming to social status variable, the rate of bachelors took $81.5 \%$, the married were at $18.5 \%$, and other variables did not realize any ratio. Consequently, this might be because the study sample generally consists of young ages with lack of experience and scarcity of financial income. Furthermore, these do not give chance to marriage; and consequently, the rates came in this form.

As for the variable of age, the ages between 21 and 30 years occupied the first rank at the rate of $72.5 \%$. This is due to the ability of this group to work in the tourist sector. Also, this is because of being qualified and dependable to form a work force for any establishment. Therefore, this is followed by the age group of 31 to 40 years at a rate of $21 \%$. Also, this resembles the former age group regarding properties and ability, but with more years of experience. The age group of less than 20 years came at the third rank with a rate of $4.3 \%$. Therefore, it is one of the needed age groups in the tourist sector especially in Craft professions which do not usually require high academic qualifications and professional capability. The age group of 41-50 took the fourth rank with $2.1 \%$ because this group has high experience and various characteristics that put it in the higher management levels. The age groups of over 50 years did not realize any worth mentioning rate.

Regarding the fourth variable, the category that have middle diploma took the first rank with a rate of $42.5 \%$. This is because of its skill level and susceptibility to work with reasonable wages compared with other academic categories. The category of general secondary or less came in the second ranked $42.1 \%$. Thus, this was followed by the bachelor's degree with $15.5 \%$. On the other hand, the category of higher studies had no rate from the study sample.

Concerning the fifth and last variable, the percentage of hotel workers was $65.7 \%$, while the ratio of tourist restaurants' workers was $34.3 \%$.

As for the other questions of the questionnaire, the distribution of workers was on all divisions especially in hotel divisions such as room service, food and drink, reception and security which are the same as in restaurants. Consequently, years of experience ranged between one year to ten years, and the most mastered language was English. 


\section{The Exploratory Study}

The study consisted of personal interviews with personnel managers and employment authorities in the tourist hotels and restaurants. The study contained thirteen questions divided over two main axes, namely: the characteristics of the expatriate labor as factor of attraction and the properties of the Jordanian labor and its points of weakness that necessitate bringing the tourist labor from abroad. The following, however, shows the nature and contents of the interviews:

\section{Characteristics of Expatriate Labor}

The expatriate labor, in the establishments where the interviews were held, forms uneven proportions. Thus, it was in a manner that does not exceed the Jordanian labor. The Egyptian nationality overwhelmed the other nationalities and the ratio of males constituted the great majority of the overall labor and the expatriate labor in particular.

The costs and wages of the expats is relatively less than those of the local labor. However, this is not a preferential advantage for the employment authorities in hotels and restaurants. This is because the expat has requirements on account of work like accommodation expenses and permit fees. Hence, this creates relative differences in costs and salaries even though it does not represent a preferential advantage for the incoming worker.

The expatriate labor is more adherent to working hours and job requirements than local labor. Personnel managers justify this aspect in that the Jordanian worker is connected to social relationships contrary to the expat. This expat is not obliged to absent himself from work and is able to work in any division and to perform any type of work like offering food and drink, cleaning toilets, and serving customers efficiently. On the other hand, this contradicts the nature and capacity of the Jordanian worker who looks at such work through the culture of shame and social level.

The most important feature that distinguishes the expat worker from the Jordanian worker is job stability as most responses revolved around the job stability enjoyed by the expatriate worker contrary to the Jordanian worker. The turnover rate of the Jordanian worker does not exceed one year. However, it is four years or more for the expat which helps supervisors and administrators to depend on expatriate labor especially in craft occupations (maintenance, housekeeping). Here, the management spends in training workers. Thus, for this reason, the management looks forward to having employees who have the ability, disposition, and continuation in work.

Job stability of the expatriate worker is probably supported by the fact that their contracts are usually annual. The incoming worker is unable to change the nature of their work and the place of work without going through 
certain procedures and getting specific permits. On the other hand, the Jordanian worker has the ability to move from one job to another.

Scientific qualification is in favor of the Jordanian labor being academically qualified. However, compared with expatriate labor, they lack practical experience especially because academic teaching does not give field training much attention. In addition, this gives advantage to the expatriate labor to replace the local labor.

Tourist hotels and restaurants are of the attractive sectors to the expatriate workers. Here, they enjoy the same privileges granted to Jordanian labor such as health insurance, social security, accommodation, and daily meals.

In fact, the expatriate workers have the capability to work longer hours than the Jordanian workers. As a result, this makes the expatriate labor more targeted and desirable by the management.

\section{Jordanian Labor}

The Jordanian labor generally prefers to work in back offices and not to directly contact and deal with customers. Personnel managers attribute this to the culture of shame and the social connections of the Jordanian worker. The divisions preferred by the Jordanian worker in hotels are the reception, the kitchen, accounting, and security. On the other hand, in restaurants, they prefer the kitchen more than the halls, i.e. usually office work.

The abundance of leaves and absence forms an intensive weakness point for the Jordanian worker. Therefore, this is because of their social relations inside Jordan in contrast with the expatriate worker who is naturally away from their social environment. This issue is relative as this point of weakness appears in the middle region like Amman. However, it lessens in Aqaba.

Tourist sector is not of attraction to the Jordanian labor. This is basically because of the economic situation and the disagreement of the tourist income with living requirements in Jordan in addition to the presence of social pressure concerning working in the tourist sector.

Nepotism is a negative aspect of the Jordanian labor as it leads to the dissatisfaction of customers with the produced services. Consequently, it characterizes the local worker with the inability to fulfill the desires of customers and highlights the advantage of the expatriate worker. The views of the respondents varied with regard to the personal traits of the local worker concerning team work spirit. Nevertheless, the majority of respondents referred to the weakness of teamwork spirit with the Jordanian worker. They stated that they do not seek to acquire working skills, but only attempt to increase their financial benefits. 
As for the comparison between local labor and expat labor in general commitment and trust in assigning tasks, the majority of the responses were positive. This is because the Jordanian worker enjoys national loyalty and looks at the tourist sector as one of the income generators.

Furthermore, local labor comply with social rules and are unable to commit mistakes because of the concept of check reference which in turn evaluates the performance of the employee. Also, it allows them to move from one working place to another. This means that they are more restricted by laws and controls than the expatriate labor.

Regarding the female local labor compared with the female expatriate labor, the answers were different. The characteristics of the expat were better than those of the local in terms of the ability to work and adapt with working hours, especially night hours. However, the local workers are more disciplined and are more governed by social regulations than the expatriate.

\section{Testing Hypotheses}

\section{1- First Hypothesis Test}

Text of First Hypothesis: "There is a positive relationship between the characteristics and specifications of the expatriate labor and their work in the Jordanian tourist sector".

The validity of the first hypothesis was verified by analyzing the questions (1-12) of the questionnaire and examining the arithmetic means and standard deviations of the Jordanian labor and the expatriate labor. Thus, this is as shown in table 5.

Table 5. The arithmetic means and standard deviations of the Jordanians' responses to the paragraphs related to the first hypothesis.

\begin{tabular}{|l|l|r|r|}
\hline $\begin{array}{l}\text { Paragraph } \\
\text { No. }\end{array}$ & Paragraph Text & $\begin{array}{l}\text { Arithmetic } \\
\text { means }\end{array}$ & $\begin{array}{l}\text { Standard } \\
\text { deviations }\end{array}$ \\
\hline 1 & The expatriate labor is more efficient than the local labor. & 2.66 & 1.12 \\
\hline 2 & The expatriate labor is more experienced than the local labor. & 2.62 & 1.04 \\
\hline 3 & The expatriate labor is more skillful than the local labor. & 2.50 & 1.09 \\
\hline 4 & $\begin{array}{l}\text { The expatriate labor is more flexible in dealing with customers than the } \\
\text { local labor. }\end{array}$ & 2.63 & 1.27 \\
\hline 5 & The expatriate labor is more cooperative with other employees. & 2.57 & 1.21 \\
\hline 6 & $\begin{array}{l}\text { The expatriate labor enjoys more personal skills (smiling, method of } \\
\text { lommunication) than the local labor. }\end{array}$ & 2.49 & 1.32 \\
\hline 7 & The expatriate labor enjoys more lingual skills than the local labor. & 2.31 & 1.20 \\
\hline 8 & $\begin{array}{l}\text { The expatriate labor is more adhered to work schedules than the local } \\
\text { labor. }\end{array}$ & 3.04 & 1.19 \\
\hline 9 & $\begin{array}{l}\text { The expatriate labor is more committed to work assignments than the local } \\
\text { labor. }\end{array}$ & 2.64 & 1.20 \\
\hline 10 & $\begin{array}{l}\text { The expatriate labor is more enduring to work pressure than the local } \\
\text { labor. }\end{array}$ & 3.76 & 1.15 \\
\hline 11 & The expatriate labor is more stable at work than the local labor. & 3.12 & 1.18 \\
\hline 12 & $\begin{array}{l}\text { The expatriate labor is more responsive to the management's requirements } \\
\text { than the local labor. }\end{array}$ & 3.09 & 1.11 \\
\hline All the paragraphs related to the first hypothesis of the Jordanians' responses & 2.79 & 0.87 \\
\hline
\end{tabular}


Examining table 5, we find that paragraph ten took the first rank with an arithmetic mean of 3.76 and a standard deviation of 1.15. This indicated that through the perspective of Jordanian labor, there is an adherence of the expatriate labor to work schedules. On the other hand, the eleventh paragraph occupied the second rank with an arithmetic mean of 3.12 and a standard deviation of 1.18, which cares for the job stability of the expatriate labor as one of its most significant features. In the third rank came paragraph twelve with an arithmetic mean of 3.09 and a standard deviation of 1.11, which deals with the subject of meeting the requirements of the management by the expatriate labor more than the local labor. In the fourth rank came paragraph eight stating that the expatriate labor is more adherent to work schedule than the local labor with an arithmetic mean of 3.04 and a standard deviation of 1.19. The first paragraph which states that the expatriate labor is more efficient than the local labor took the fifth rank with an arithmetic mean of 2.66 and a standard deviation of 1.12. This was followed by paragraph nine which says that the expatriate labor is more committed to work assignments than the local labor with an arithmetic mean of 2.64 and a standard deviation of 1.20. After that came the fourth paragraph which stated that the expatriate labor is more cooperative with other employees with an arithmetic mean of 2.63 and a standard deviation of 1.27. The eighth rank was for the second paragraph which states that the expatriate labor is more experienced than the local labor with an arithmetic mean of 2.62 and a standard deviation of 1.04. After the ninth rank came the fifth paragraph. This states that the expatriate labor is more cooperative with other employees with an arithmetic mean of 2.57 and a standard deviation of 1.21 . The third paragraph which indicated that the expatriate labor is more skillful than the local labor came in the tenth rank with an arithmetic mean of 2.50 and a standard deviation of 1.09. The sixth paragraph that stated that the expatriate labor enjoys more personal skills than local labor took the eleventh rank with an arithmetic mean of 2.49 and a standard deviation of 1.32. Furthermore, the twelfth and last rank was taken by paragraph seven which stated that the expatriate labor has more lingual skills than the local labor with an arithmetic mean of 2.31 and a standard deviation of 1.20.

Consequently, we see from the table that the Jordanian labor was denied as it realized all the paragraphs with an arithmetic mean of 2.79 and a standard deviation of 0.87 .

Furthermore, in order to identify the responses of the sample members of expatriate workers, the arithmetic means and standard deviations were calculated for the same previous questions. Thus, this is shown in table 6. 
Table 6. The arithmetic means and standard deviations of the responses of the sample members of expatriate labor to the paragraphs related to the first hypothesis

\begin{tabular}{|l|l|r|r|}
\hline No. & Paragraph Text & $\begin{array}{l}\text { Arithmetic } \\
\text { means }\end{array}$ & $\begin{array}{l}\text { Standard } \\
\text { deviations }\end{array}$ \\
\hline 1 & The expatriate labor is more efficient than the local labor. & 3.16 & 0.99 \\
\hline 2 & The expatriate labor is more experienced than the local labor. & 2.99 & 1.08 \\
\hline 3 & The expatriate labor is more skillful than the local labor. & 3.08 & 1.19 \\
\hline 4 & $\begin{array}{l}\text { The expatriate labor is more flexible in dealing with customers } \\
\text { than the local labor. }\end{array}$ & 2.83 & 1.07 \\
\hline 5 & The expatriate labor is more cooperative with other employees & 2.33 & 0.85 \\
\hline 6 & $\begin{array}{l}\text { The expatriate labor enjoys more personal skills (smiling, } \\
\text { method of communication) than the local labor. }\end{array}$ & 2.67 & 0.94 \\
\hline 7 & $\begin{array}{l}\text { The expatriate labor enjoys more lingual skills than the local } \\
\text { labor. }\end{array}$ & 2.41 & 0.95 \\
\hline 8 & $\begin{array}{l}\text { The expatriate labor is more adhered to work schedules than } \\
\text { the local labor. }\end{array}$ & 3.00 & 0.91 \\
\hline 9 & $\begin{array}{l}\text { The expatriate labor is more committed to work assignments } \\
\text { than the local labor. }\end{array}$ & 2.91 & 1.12 \\
\hline 10 & $\begin{array}{l}\text { The expatriate labor is more enduring to work pressure than the } \\
\text { local labor. }\end{array}$ & 3.74 & 094 \\
\hline 11 & The expatriate labor is more stable at work than the local labor. & 3.40 & 0.87 \\
\hline 12 & $\begin{array}{l}\text { The expatriate labor is more responsive to the management's } \\
\text { requirements than the local labor. }\end{array}$ & 3.40 & 1.12 \\
\hline $\begin{array}{l}\text { All the paragraphs related to the first hypothesis of the Jordanians' } \\
\text { responses }\end{array}$ & 2.99 & 0.64 \\
\hline
\end{tabular}

Table 6 shows that paragraph ten occupied the first rank with an arithmetic mean of 3.74 and a standard deviation of 0.94 . Therefore, this resembles and accords with the responses of the sample members of Jordanian labor. The same holds for the second rank which was occupied by paragraph eleven and twelve with an arithmetic mean of 3.40 and a standard deviation of 0.87 and 1.12, respectively. The first paragraph which states that the expatriate labor is more efficient than the local labor took the fourth rank with an arithmetic mean of 3.16 and a standard deviation of 0.99 . The fifth rank was taken by the third paragraph which states that the expatriate labor is more skillful than the local labor with an arithmetic mean of 3.08 and a standard deviation of 1.19. The eighth paragraph which states that the expatriate labor is more adherent to the work schedule than the local labor came in as the sixth rank with an arithmetic mean 3.00 and a standard deviation 0.91 . However, the second paragraph which says that the expatriate labor is more experienced than the local labor took the seventh rank with an arithmetic mean of 2.99 and a standard deviation of 1.08. The ninth paragraph came in as the eighth sixth with an arithmetic mean of 2.91 and a standard deviation of 1.12. Paragraph four took the ninth sixth rank with an arithmetic mean of 2.83 and a standard deviation of 1.07. The sixth 
paragraph that states that the expatriate labor enjoys more personal skills (smile, method of communication) than the local labor took the tenth rank with an arithmetic mean of 2.67 and a standard deviation of 0.94 . Thus, this was followed by paragraph seven which handled the subject of lingual skills of the expatriate labor in the eleventh rank with an arithmetic mean of 2.41 and a standard deviation of 0.95. Finally, paragraph five came in as the twelfth and last rank with an arithmetic mean of 2.33 and a standard deviation of 0.85 .

Table 6 reveals the denial of the first hypothesis by the expatriate labor, yet more positively than the responses of the local labor. This is based on the fact that the questions related to the first hypothesis were realized as an arithmetic mean of 2.99 and a standard deviation of 0.64 .

As for examining the statistical significances of the independent variables of the sample, in the members' responses related to the first hypothesis, t-test was carried out for the variables that consist of two types. Also, F-value test was performed for the variables that consist of more than two types as well as the significances level. Table 7 shows the t-test.

Table 7. T-test and the significance level of the independent variables related to the first hypothesis

\begin{tabular}{|c|c|c|c|c|c|c|}
\hline $\begin{array}{l}\text { No } \\
\text { H }\end{array}$ & Variable & Types of variables & $\begin{array}{l}\text { Arithmeti } \\
\text { c mean }\end{array}$ & $\begin{array}{l}\text { Standard } \\
\text { deviation }\end{array}$ & $\begin{array}{l}\mathrm{T} \\
\text { value }\end{array}$ & $\begin{array}{l}\text { Signific } \\
\text { ance } \\
\text { level }\end{array}$ \\
\hline \multirow{8}{*}{ H1 } & \multirow{2}{*}{ Nationality } & Jordanian & 2.79 & 0.871 & \multirow{2}{*}{$\begin{array}{r}2.091 \\
-\end{array}$} & \multirow{2}{*}{0.038} \\
\hline & & Expat & 2.99 & 0.637 & & \\
\hline & \multirow{2}{*}{ Gender } & Male & 2.87 & 0.796 & \multirow{2}{*}{$\begin{array}{r}1.304 \\
-\end{array}$} & \multirow{2}{*}{0.194} \\
\hline & & Female & 3.05 & 0.528 & & \\
\hline & \multirow{2}{*}{ Social status } & Single & 2.86 & 0.691 & \multirow{2}{*}{$\begin{array}{r}1.473 \\
-\end{array}$} & \multirow{2}{*}{0.142} \\
\hline & & Married & 3.05 & 1.025 & & \\
\hline & \multirow{2}{*}{ Tourist activity } & Hotel & 2.71 & 0.737 & \multirow{2}{*}{$\begin{array}{r}5.364 \\
-\end{array}$} & \multirow{2}{*}{0.000} \\
\hline & & Tourist restaurant & 3.24 & 0.692 & & \\
\hline
\end{tabular}

The table above indicates the existence of statistically significant differences at the significance level $\mathrm{a} \geq 0.05$ for the nationality variable. However, this was where the significance level reached at 0.038 in favor of the expatriate labor. This was as the responses of the expats were more positive than those of the local labor. The arithmetic mean of the overall paragraph of the first hypothesis for the responses of the sample members of the expatriate labor was 2.99. On the other hand, it was 2.79 regarding the Jordanian workers. This could be due to the fact that the questions of the first hypothesis were subjective. In addition, it is concerned with the personal skills which the expatriate worker is more capable to assess than the 
Jordanian worker. Therefore, this is regarding the extent of the availability of the expat worker.

We also noticed in table 7 that there are no statistically significant differences at $\mathrm{a} \geq 0.05$ for the variables of gender and social status. This is because the significance level for gender showed 0.194 and 0.142 for social status. The absence of statistically significant differences due to gender could be attributed to the fact that work nature, conditions, and requirements are usually the same for both genders. Consequently, no statistically significant differences were produced.

The above stated table also shows statistically significant differences due to the variable of tourist activity at the significance level a $\geq 0.05$ where the significance level of the tourist activity variable was 0.000 . Thus, this is in favor of the sample members who are working in tourist restaurants whereupon the arithmetic mean was 3.24. On the other hand, the arithmetic mean of the responses of the sample members who are working in hotels was 2.71. Hence, this could be because of the exiguity of the tourist restaurant sections in comparison with hotels. This promotes the ability of respondents to respond and specify the differences accurately. In addition, the expatriate workers are more in existence in the tourist restaurants than in hotels. However, this justifies the existence of statistically significant differences.

To recognize if there were statistically significant differences due to the variables of age and educational level, $\mathrm{F}$ value and the significance level for each of the two variables were calculated as indicated in table 8. Table 8. F value and significance level for the independent variables related to the first hypothesis

\begin{tabular}{|c|c|c|c|c|c|c|}
\hline $\begin{array}{l}\text { No. of } \\
\text { hypothe } \\
\text { sis }\end{array}$ & Variable & Type of variable & $\begin{array}{l}\text { Arithm } \\
\text { etic } \\
\text { mean } \\
\end{array}$ & $\begin{array}{l}\text { Standard } \\
\text { deviation }\end{array}$ & $\begin{array}{l}\text { Val } \\
\text { ue } \\
\text { "F" }\end{array}$ & $\begin{array}{l}\text { Significan } \\
\text { ce level }\end{array}$ \\
\hline \multirow{7}{*}{ H 1} & \multirow{4}{*}{ Age } & 20 and less & 2.21 & 0.747 & \multirow{4}{*}{$\begin{array}{r}3.3 \\
37\end{array}$} & \multirow{4}{*}{0.020} \\
\hline & & $21-30$ & 2.89 & 0.691 & & \\
\hline & & $31-40$ & 3.01 & 0.965 & & \\
\hline & & $41-50$ & 3.17 & 0.00 & & \\
\hline & \multirow{3}{*}{$\begin{array}{l}\text { Education } \\
\text { al level }\end{array}$} & $\begin{array}{ll}\text { General secondary } \\
\text { and less }\end{array}$ & 2.89 & 0.644 & \multirow{3}{*}{$\begin{array}{r}0.2 \\
91\end{array}$} & \multirow{3}{*}{0.748} \\
\hline & & Middle diploma & 2.93 & 0.735 & & \\
\hline & & Bachelor's degree & 2.82 & 1.095 & & \\
\hline
\end{tabular}

Through the above stated table, we noticed the existence of statistically significant differences due to age variable at a $\geq 0.05$. Here, the significance level of age was 0.020 which is statistically significant.

It is also possible to consider the existence of statistically significant differences due to age variable. Thus, this variable is basically connected to the ability and desire of the worker and their motivation and acceptance to 
work conditions. Therefore, the responses vary and reveal statistical differences as clarified in table 13.

\begin{tabular}{|c|c|c|c|c|}
\hline $\begin{array}{l}\text { Table 9. The } \\
\text { differences in } \\
\text { the sample } \\
\text { members' } \\
\text { responses about } \\
\text { the study } \\
\text { paragraphs } \\
\text { related to the } \\
\text { first hypothesis } \\
\text { divided with the } \\
\text { variable of age } \\
\text { No. } \\
\text { hypothesis of }\end{array}$ & Basic age group & $\begin{array}{l}\text { Comparative } \\
\text { age group }\end{array}$ & $\begin{array}{l}\text { Differences in the } \\
\text { means }\end{array}$ & $\begin{array}{l}\text { Significance } \\
\text { level }\end{array}$ \\
\hline \multirow{12}{*}{ H1 } & \multirow{3}{*}{20 and less } & $30-21$ & -0.69 & 0.52 \\
\hline & & $40-31$ & $-0.80 *$ & 0.028 \\
\hline & & $50-41$ & -0.96 & 0.148 \\
\hline & \multirow{3}{*}{$21-30$} & 20 and less & 0.69 & 0.052 \\
\hline & & 40-31 & -0.11 & 0.843 \\
\hline & & $50-41$ & -0.27 & 0.888 \\
\hline & \multirow{3}{*}{$31-40$} & 20 and less & $0.80 *$ & 0.028 \\
\hline & & 30-21 & 0.11 & 0.834 \\
\hline & & $50-41$ & -0.16 & 0.976 \\
\hline & \multirow{3}{*}{$41-50$} & 20 and less & 0.96 & 0.148 \\
\hline & & $30-21$ & 0.27 & 0.888 \\
\hline & & $40-31$ & 0.16 & 0.976 \\
\hline
\end{tabular}

Through the above stated table, we find that there are no statistically significant differences between the age group 20 and less, and the age groups of 31-40 and 41-50. On the other hand, there are statistically significant differences between the age group of 20 and less, and the age group of 3140. This is based on the fact the age group of 31-40 has acquired tourist experience and the ability to respond. Thus, this differs from the age group of 20 and less. Also, this has less experience and usually practices craft work. There were no statistically significant differences between the age group of 31-40 and other age groups. Similarly, there were no statistically significant differences between the age group of 41-50 and other age groups.

Table 8 indicates that there are no statistically significant differences due to the educational level variable at $a \geq 0.05$. This is because the significance difference of the educational level was 0.748, which is statistically insignificant.

\section{2- Second Hypothesis Test}

Text of Second Hypothesis: "There is a positive relationship between the tourist work environment and the employment of expatriate labor in the Jordanian tourist sector." 
However, the validity of the second hypothesis was verified by analyzing questions (13-28) of the questionnaire and studying the arithmetic means and standard deviations of each of the Jordanian and expatriate labor. This is as shown in table 10 .

Table 10. The arithmetic means and standard deviations of the paragraphs related to the second hypothesis of the Jordanians' responses

\begin{tabular}{|l|l|r|r|}
\hline $\begin{array}{l}\text { No } \\
\text { Paragraph Text }\end{array}$ & $\begin{array}{l}\text { Arithmet } \\
\text { ic means }\end{array}$ & \multicolumn{1}{|l|}{$\begin{array}{l}\text { Standard } \\
\text { deviation } \\
\text { s }\end{array}$} \\
\hline 13 & Work laws are encouraging to attract expatriate labor. & 4.00 & 0.30 \\
\hline 14 & Expatriate labor agrees to work longer hours than local labor. & 3.74 & 0.94 \\
\hline 15 & Managements take advantage of expatriate labor. & 3.96 & 0.69 \\
\hline 16 & $\begin{array}{l}\text { Work provides appropriate social warranties (health insurance, } \\
\text { social security). }\end{array}$ & 3.91 & 0.59 \\
\hline 17 & $\begin{array}{l}\text { The employing organizations provide promotive advantages } \\
\text { (accommodation, transportation). }\end{array}$ & 4.10 & 0.67 \\
\hline 18 & $\begin{array}{l}\text { Job provides training courses for expats to develop their work } \\
\text { skills. }\end{array}$ & 3.37 & 0.95 \\
\hline 19 & Job provides health insurance for expats against work injuries. & 3.43 & 1.10 \\
\hline 20 & Job provides daily meals for expats. & 3.08 & 1.06 \\
\hline 21 & Work shifts are properly distributed among all employees. & 3.56 & 0.91 \\
\hline 22 & Work provides living stability for the expat and his family. & 3.48 & 1.14 \\
\hline 23 & The expatriate worker feels comparison with his Jordanian peers. \\
\hline 24 & Expatriate workers accept less wages than local workers. & 3.33 & 1.16 \\
\hline 25 & $\begin{array}{l}\text { The incentive and promotion system for expatriate labor is } \\
\text { unfair. }\end{array}$ & 3.10 & 1.48 \\
\hline 26 & There are no paid leaves for expats. & 3.08 & 0.98 \\
\hline 27 & $\begin{array}{l}\text { The Jordanian tourist sector is an attraction factor for expatriate } \\
\text { labor. }\end{array}$ & 4.06 & 1.11 \\
\hline 28 & $\begin{array}{l}\text { The advantages of the expatriate labor in the tourism sector are } \\
\text { better than those of other sectors. }\end{array}$ & 4.20 & 0.72 \\
\hline $\begin{array}{l}\text { All } \text { the paragraphs related to the second hypothesis of the Jordanians' } \\
\text { responses }\end{array}$ & 3.61 & 0.39 \\
\hline
\end{tabular}

Table 10 shows that the twenty-eighth paragraph about the advantages of the Jordanian tourist sector occupied the first rank with an arithmetic mean of 4.20 and a standard deviation of 0.72 . On the other hand, paragraph seventeen about providing incentives took the second rank with an arithmetic mean of 4.10 and a standard deviation of 0.67 . The third rank was taken by paragraph twenty-seven which states that the tourist sector is an attraction factor for expatriate labor. However, it has an arithmetic mean of 4.06 and a standard deviation of 1.11. Paragraph thirteen which states that work laws are encouraging in attracting expatriate labor, took the fourth rank with an arithmetic mean of 4.00 and a standard deviation of 0.30. Paragraph fifteen took the fifth rank with an arithmetic mean of 3.96 and a standard deviation of 0.69 . This was followed by paragraph sixteen with an arithmetic 
mean of 3.91 and a standard deviation of 0.59 . The seventh rank was taken by paragraph fourteen with an arithmetic mean of 3.74 and a standard deviation of 0.94 . Furthermore, paragraph twenty-one took the eighth rank with an arithmetic mean of 3.56 and a standard deviation of 0.91 .

The twenty-third paragraph came in the ninth rank with an arithmetic mean of 3.48 and a standard deviation of 1.03 .

In the tenth rank come paragraph nineteen with an arithmetic mean of 3.43 and a standard deviation of 1.10. Paragraph twenty-two took rank eleven with an arithmetic mean of 3.38 and a standard deviation of 1.14. The eighteenth paragraph took the twelfth rank with an arithmetic mean of 3.37 and a standard deviation of 0.95. However, in rank thirteen came paragraph twenty-four with an arithmetic mean of 3.33 and a standard deviation of 1.16. This was followed by the twenty- fifth paragraph in the fourteenth rank with an arithmetic mean of 3.10 and a standard deviation of 1.48. Finally came paragraphs twenty and twenty-six with an arithmetic mean of 3.08 and a standard deviation of 0.91 and 0.98 , respectively.

Through table 11, we notice that the local labor affirmed the second hypothesis. This is because the questions related to the second hypothesis achieved an arithmetic mean of 3.619 and a standard deviation of 0.39 .

Therefore, in order to know the responses of the sample members of the expatriate labor, the arithmetic means and standard deviation of the same former questions were calculated. Hence, this was revealed in table 11.

Table 11. The arithmetic means and standard deviations of the expatriate labor sample members to the paragraphs related to the second hypothesis

\begin{tabular}{|l|l|r|r|}
\hline $\begin{array}{l}\text { N } \\
\text { o. }\end{array}$ & Paragraph Text & $\begin{array}{l}\text { Arithm } \\
\text { etic } \\
\text { means }\end{array}$ & \multicolumn{1}{|c|}{$\begin{array}{l}\text { Standar } \\
\text { d } \\
\text { deviatio } \\
\text { ns }\end{array}$} \\
\hline 13 & Work laws are encouraging to attract expatriate labor. & 3.50 & 0.96 \\
\hline 14 & Expatriate labor agrees to work longer hours than local labor. & 4.00 & 1.08 \\
\hline 15 & Managements take advantage of expatriate labor. & 3.82 & 1.00 \\
\hline 16 & $\begin{array}{l}\text { Work provides appropriate social warranties (health insurance, } \\
\text { social security). }\end{array}$ & 4.00 & 0.71 \\
\hline 17 & $\begin{array}{l}\text { The employing organizations provide promotive advantages } \\
\text { (accommodation, transportation). }\end{array}$ & 3.92 & 0.49 \\
\hline 18 & Job provides training courses for expats to develop their work skills. & 3.26 & 0.93 \\
\hline 19 & Job provides health insurance for expats against work injuries. & 3.42 & 0.76 \\
\hline 20 & Job provides daily meals for expats. & 3.59 & 0.76 \\
\hline 21 & Work shifts are properly distributed among all employees. & 3.50 & 0.87 \\
\hline 22 & Work provides living stability for the expat and his family. & 2.93 & 1.12 \\
\hline 23 & The expatriate worker feels comparison with his Jordanian peers. & 3.00 & 0.82 \\
\hline 24 & Expatriate workers accept less wages than local workers. & 3.98 & 0.93 \\
\hline 25 & The incentive and promotion system for expatriate labor is unfair. & 3.31 & 1.05 \\
\hline 26 & There are no paid leaves for expats. & 3.16 & 1.07 \\
\hline
\end{tabular}




\begin{tabular}{|c|l|r|r|}
\hline 27 & $\begin{array}{l}\text { The Jordanian tourist sector is an attraction factor for expatriate } \\
\text { labor. }\end{array}$ & 3.65 & 1.12 \\
\hline 28 & $\begin{array}{l}\text { The advantages of the expatriate labor in the tourism sector are } \\
\text { better than those of other sectors. }\end{array}$ & 4.34 & 0.48 \\
\hline $\begin{array}{l}\text { All the paragraphs related to the second hypothesis of the Jordanians' } \\
\text { responses }\end{array}$ & 3.59 & 0.35 \\
\hline
\end{tabular}

Table 11 shows that paragraph twenty-eight, which indicated that the advantages of the expatriate labor in the tourist sector are better than those of other sectors, occupied the first rank with an arithmetic mean of 4.43 and a standard deviation of 0.48. Paragraphs fourteen and sixteen came in the second rank with an arithmetic mean of 4.00 and a standard deviation of 1.08 and 0.71 , respectively. The fourth rank was taken by the paragraph which stated that the expatriate labor accepts lower wages than the local labor with an arithmetic mean of 3.98 and a standard deviation of 0.93. Paragraph seventeen took the second fifth rank with an arithmetic mean of 3.92 and a standard deviation of 0.49 . In the sixth rank came the second fifteenth with an arithmetic mean of 3.82 and a standard deviation of 1.00. In the seventh rank came the second twenty-seventh paragraph with an arithmetic mean of 3.65 and a standard deviation of 1.12. Furthermore, then came the twentyfive paragraph in the second eighth rank with arithmetic mean of 3.59 and a standard deviation of 0.59 . The ninth rank was taken by the thirteenth and the second twenty second paragraphs with an arithmetic mean of 3.50 and standard deviations of 0.96 and 0.87 . Then, it was followed by the nineteenth paragraph in the second eleventh rank with arithmetic mean of 3.42 and a standard deviation of 0.76 . In the twelfth rank came the second twenty-fifth paragraph with an arithmetic mean of 3.31 and a standard deviation of 1.05. In the fourteenth rank came the second eighteenth paragraph with an arithmetic mean of 3.26 and a standard deviation of 0.9. Then, it was followed by the second twenty-sixth paragraph with an arithmetic mean of 3.16 and a standard deviation of 1.07. In the rank before the last came the second twenty-third paragraph with an arithmetic mean of 3.00 and a standard deviation of 0.82. In addition, the last rank was taken by the twentysecond paragraph that had an arithmetic mean of 2.93 and a standard deviation of 1.12 .

Table 11 also shows the confirmation of the second hypothesis by the expatriate labor. Here, the questions related to the second hypothesis realized an arithmetic mean of 3.59 with a standard deviation of 0.35 .

Concerning studying the statistical significances of the independent variables of the sample members' responses related the second hypothesis, the T-test of the variables that consist of two types, $\mathrm{F}$ value of the variables that consist of more than two types, and the significance level were calculated. However, table 12 clarifies T-test. 
Table 12. T-test and significance level of the independent variables related to the second hypothesis

\begin{tabular}{|c|c|c|c|c|c|c|}
\hline $\begin{array}{l}\mathbf{N} \\
\mathbf{0} \\
\mathbf{H}\end{array}$ & Variable & $\begin{array}{l}\text { Types of } \\
\text { variables }\end{array}$ & $\begin{array}{l}\text { Arithm } \\
\text { etic } \\
\text { mean }\end{array}$ & $\begin{array}{l}\text { Standa } \\
\text { rd } \\
\text { deviati } \\
\text { on } \\
\end{array}$ & T value & $\begin{array}{l}\text { Significan } \\
\text { ce level }\end{array}$ \\
\hline \multirow{8}{*}{$\begin{array}{l}\mathbf{H} \\
2\end{array}$} & \multirow{2}{*}{ Nationality } & Jordanian & 3.61 & 0.388 & \multirow[t]{2}{*}{0.500} & \multirow[t]{2}{*}{0.618} \\
\hline & & Expat & 3.59 & 0.352 & & \\
\hline & \multirow{2}{*}{ Gender } & Male & 3.62 & 0.329 & \multirow[t]{2}{*}{2.455} & \multirow[t]{2}{*}{0.015} \\
\hline & & Female & 3.46 & 0.534 & & \\
\hline & \multirow{2}{*}{ Social status } & Single & 3.60 & 0.372 & \multirow[t]{2}{*}{0.096} & \multirow[t]{2}{*}{0.924} \\
\hline & & Married & 3.59 & 0.385 & & \\
\hline & \multirow{2}{*}{$\begin{array}{l}\text { Tourist } \\
\text { activity }\end{array}$} & Hotel & 3.67 & 0.316 & \multirow[t]{2}{*}{3.985} & \multirow[t]{2}{*}{0.000} \\
\hline & & Tourist restaurant & 3.47 & 0.427 & & \\
\hline
\end{tabular}

From the previous table, we noticed that there are no statistically significant differences at the significance level $a \geq 0.05$ for the variable of nationality. This is because the significance level of the nationality variable was 0.618. This could be because the questions related to the second hypothesis enjoy a consensus that tourism is an attractive sector to workers. It also states that the expatriate labor is able to adapt with the requirements and terms of tourist work.

Table 12 indicates statistically significant differences at the significance level $\mathrm{a} \geq 0.05$ pursuant to the gender variable as the significance level of gender reached 0.015 . This is in favor of males as the arithmetic mean of the males' responses was 3.62, while it was 3.46 regarding the females. Furthermore, this could be attributed to the fact that males are more adaptive to the requirements of tourist work concerning the times and shifts of work.

As for the social status variable, there are no statistically significant differences at the significance level $\mathrm{a} \geq 0.05$ for the social status variable where the significance level was 0.924 . This could be because of the absence of statistically significant differences due to social status. Thus, it was previously mentioned that tourism is an attractive sector and is able to meet the needs of beneficiary individuals and families.

The above stated table also reveals statistically significant differences due to the tourist activity variable at the significance level $\mathrm{a} \geq 0.05$ where the significance level of tourist activity variable was 0.000 . This is in favor of the responses of the sample members who are working at hotels as the arithmetic mean reached 3.67. On the other hand, the arithmetic mean of the responses of the sample members who are working at tourist restaurants was 3.47. This could be because of the fewness of the restaurants' divisions compared with hotels. Also, it is as a result of the clarity of the job 
requirements and the functional description in hotels which make work conditions clearer than tourist restaurants.

In order to see whether there were statistically significant differences due to the variables of age and educational level, $\mathrm{F}$ value and the significance level of each of the two variables were calculated. However, this was clarified in table 13.

Table 13. F value and significance level of the independent variables related to the second hypothesis

\begin{tabular}{|c|c|c|c|c|c|c|}
\hline $\begin{array}{l}\text { No. of } \\
\text { hypot } \\
\text { hesis }\end{array}$ & Variable & Type of variable & $\begin{array}{l}\text { Arithm } \\
\text { etic } \\
\text { mean }\end{array}$ & $\begin{array}{l}\text { Standa } \\
\text { rd } \\
\text { deviati } \\
\text { on }\end{array}$ & $\begin{array}{l}\text { Value } \\
\text { "F" }\end{array}$ & $\begin{array}{l}\text { Signific } \\
\text { ance } \\
\text { level }\end{array}$ \\
\hline \multirow{7}{*}{ H 2} & \multirow{4}{*}{ Age } & 20 and less & 3.13 & 0.066 & \multirow{4}{*}{$\begin{array}{r}23.365 \\
7\end{array}$} & \multirow{4}{*}{0.000} \\
\hline & & $21-30$ & 3.67 & 0.317 & & \\
\hline & & $31-40$ & 3.54 & 0.390 & & \\
\hline & & $41-50$ & 2.69 & 0.00 & & \\
\hline & \multirow{3}{*}{$\begin{array}{l}\text { Educational } \\
\text { level }\end{array}$} & $\begin{array}{l}\text { General secondary } \\
\text { and less }\end{array}$ & 3.70 & 0.281 & \multirow[t]{3}{*}{7.158} & \multirow[t]{3}{*}{0.001} \\
\hline & & Middle diploma & 3.52 & 0.452 & & \\
\hline & & Bachelor's degree & 3.54 & 0.246 & & \\
\hline
\end{tabular}

The above table shows statistically significant differences due to the variables of age at the significance level $\mathrm{a} \geq 0.05$, where the significance level of age reached 0.020 which is statistically significant.

Subsequently, we can also consider the existence of statistically significant differences due to age. However, this variable is connected to the ability, desire, and acceptance of the worker to work conditions. Also, it depends on the capacity of the tourist sector to attract labor. Therefore, the response varies and shows statistical differences as clarified in table 14.

Table 14. The differences in the responses of the sample members about the study paragraphs related to the second hypothesis divided according to age variable

\begin{tabular}{|c|c|c|c|c|}
\hline $\begin{array}{l}\text { No. of } \\
\text { hypothesis }\end{array}$ & $\begin{array}{l}\text { Basic } \\
\text { age } \\
\text { group }\end{array}$ & $\begin{array}{l}\text { Comparative } \\
\text { age group }\end{array}$ & $\begin{array}{l}\text { Differences } \\
\text { in the } \\
\text { means }\end{array}$ & $\begin{array}{l}\text { Significance } \\
\text { level }\end{array}$ \\
\hline \multirow{12}{*}{ H2 } & \multirow{3}{*}{$\begin{array}{l}20 \\
\text { and } \\
\text { less }\end{array}$} & $30-21$ & $-0.54^{*}$ & 0.00 \\
\hline & & $40-31$ & $-0.42^{*}$ & 0.004 \\
\hline & & $50-41$ & 0.44 & 0.113 \\
\hline & \multirow{3}{*}{$21-30$} & 20 and less & $0.54 *$ & 0.000 \\
\hline & & $40-31$ & 0.13 & 0.118 \\
\hline & & $50-41$ & 0.98* & 0.000 \\
\hline & \multirow{3}{*}{$31-40$} & 20 and less & $0.42 *$ & 0.004 \\
\hline & & $30-21$ & -0.13 & 0.118 \\
\hline & & $50-41$ & $0.85^{*}$ & 0.000 \\
\hline & \multirow{3}{*}{$41-50$} & 20 and less & -0.44 & 0.113 \\
\hline & & $30-21$ & $-0.98^{*}$ & 0.000 \\
\hline & & $40-31$ & $-0.85 *$ & 0.000 \\
\hline
\end{tabular}


In the previous table, we noticed statistically significant differences between the age group 20 years or less, and the two age groups 21-30 and 31-40. Thus, this is because of the ability of this group to deal more flexibly with the requirements of tourist work and to adapt with its conditions, especially regarding night shifts which differ from the former two groups which are linked to social factors.

The former table also reveals statistically significant differences between age group 21-30 and age group 41-50 in favor of the age group 2130. It is more adaptable with tourist work conditions because of age. Also, seasonal income is contrary to old age groups. However, this is the same as when comparing age group 31-40 with age group 41-50. We can conclude that the older the age group, the less able it is to conform with the requirements and conditions of tourist work.

Table 13 points out statistically significant differences due to the variable of educational level at the significance level of $a \geq 0.05$ where the significance level of the educational level variable was 0.001 which is statistically significant.

Furthermore, there are also statistically significant differences attributed to the variable of educational level. Thus, this variable is connected to the academic and professional qualification of the worker and consequently to his acceptance and ability to adapt with the work conditions. Therefore, the responses vary and produce statistical differences. This is clarified in table 15.

Table 15. The differences in the sample members' responses about the study paragraphs

related to the second hypothesis divided according to the educational level variable

\begin{tabular}{|l|l|l|l|l|}
\hline $\begin{array}{l}\text { No. of } \\
\text { hypothesis }\end{array}$ & $\begin{array}{l}\text { Basic } \\
\text { educational } \\
\text { level group }\end{array}$ & $\begin{array}{l}\text { Comparative } \\
\text { educational level } \\
\text { group }\end{array}$ & $\begin{array}{l}\text { Differences in the } \\
\text { means }\end{array}$ & $\begin{array}{l}\text { Significa } \\
\text { nce level }\end{array}$ \\
\hline \multirow{4}{*}{ H2 } & $\begin{array}{l}\text { General } \\
\text { secondary and } \\
\text { less }\end{array}$ & Middle diploma & $0.19^{*}$ & 0.002 \\
\cline { 2 - 5 } & $\begin{array}{l}\text { Middle } \\
\text { diploma }\end{array}$ & $\begin{array}{l}\text { General secondary } \\
\text { and less }\end{array}$ & $-0.19^{*}$ & 0.067 \\
\cline { 2 - 5 } & Bachelor's degree & -0.02 & 0.002 \\
\cline { 2 - 5 } & $\begin{array}{l}\text { Bachelor's } \\
\text { degree }\end{array}$ & $\begin{array}{l}\text { General secondary } \\
\text { and less }\end{array}$ & -0.16 & 0.118 \\
\cline { 3 - 5 } & Middle diploma & 0.02 & 0.067 \\
\hline
\end{tabular}

Through the above mentioned table, we noticed statistically significant differences between the category of general secondary and less, and the category of middle diploma. However, this is in favor of the general secondary category because the work conditions and the income realized for the general secondary and less are more acceptable than for the middle diploma. This is especially with the approximate income for both categories. 
On the other hand, the table has not indicated any other statistically significant differences.

\section{Results}

After conducting this study, the following results were produced:

1- The Jordanian work market is two-way i.e. it is a sender and receiver market for labor. Here, the service sector occupies the first rank in importing labor and the sector of constructions receives the least ratio.

2- The expatriate labor represents $17.6 \%$ of the total labor in the Jordanian tourist sector, most of which are concentrated in hotels and tourist restaurants.

3- The expatriate tourist labor mostly exists in hotels and tourist restaurants where they formed nearly $11.3 \%$ in hotels in 2015 . This is because of the variety of their sections and services (accommodation, food, drink, entertainment etc.). Also, the ratio of expatriate workers in restaurants was nearly $32.4 \%$ in 2015. This is because of the big number of restaurants and the need for certain number of employees in different specializations to meet the various and diverse desires. In addition to that is the ability of those restaurants to present their services to local customers which lessens the seasonal work for them.

4- The characteristics of Jordanian tourist labor are:

a) Tourism is one of the Jordanian sectors that do not attract local labor because they believe that the income is not appropriate for living demands and social pressure. Thus, this is despite the availability of opportunities and academic qualifications that represent a strength point and advantage over the rest of labor in the Jordanian tourist sector.

b) Tourist labor prefers office work which does not involve direct connection with customers (Back office) like security, reception, accounting, and the kitchen.

c) The Jordanian labor is characterized by muchness of leaves and absence and dependence on social relations in employment. However, this negatively reflects on the reputation of the Jordanian tourist labor in general.

d) Work turnover and job stability are the weakest points of the Jordanian tourist labor which might be the reason behind substituting it with expatriate labor.

e) The Jordanian tourist labor has weakness in the teamwork spirit and lack in attaining work skills and experiences. Thus, it only seeks to increase its financial income. 
5- The characteristics of the expatriate labor in Jordan are:

a) The Jordanian tourist sector is one of the attractive sectors to expatriate labor because of its appropriate income and conditions of food, accommodation, and social and health guarantees.

b) The cost of expatriate labor is relatively less than local labor, but this does not form a preferential advantage over the local labor.

c) The expatriate labor adheres to work schedule and executes work assignments.

d) Work turnover and job stability are the basic advantages that distinguish the expatriate labor from local labor.

e) The expatriate labor in the Jordanian tourist sector is complementary, and is not a substitute for the tourist professions that require terms and conditions which are not available on the local level. Also, the local labor is not qualified to fulfill them.

6- The advantages of the expatriate labor are not preferential in employment because the academic and scientific skills are available with the local labor in relative comparison to the expatriate labor.

7- The tourist sector is attractive to the expatriate labor in general. Also, the hotel work environment is the most appropriate and attractive to the expatriate labor because of its multiple divisions and clear job tasks more than restaurants. Thus, the work environment constitutes pressure on the worker in general.

\section{Recommendation}

After conducting this study, the researcher recommends the following to replace the expatriate labor with local labor in the Jordanian tourist sector:

- Developing local tourist workers by holding courses for the Jordanian workers in the tourist hotels and restaurants and training them on lingual and specialized tasks.

- Assessing work skills and experiences of the Jordanian employees on periodical terms to determine and develop shortages.

- Specifying job tasks for each employee by giving them functional description of this job, way of performance, and the required time to accomplish it. This is in addition to sharing them in planning and distributing work shifts.

- Holding local courses and symposiums to acknowledge the tourist activity, its importance, and its ability to fulfill the living requirements of the tourist employee. This makes the tourist income include three, namely: the basic salary, point of services, and the tips of customers. 
- Holding promotional campaigns that demonstrate the nature, requirements, and advantages of tourist work in order to increase the local tourist labor offer to conform to the present and future demands.

- Highlighting the successful Jordanian labor experiences in the tourist sector to stimulate local societies to enter the tourist work market and to promote the current abilities of the workers.

- Creating a new method for admission into the specializations related to tourist activity in all Jordanian governmental and private universities. This is done in a way that the admission would not depend just on the general secondary rate, but also on personal interviews that measure the knowledge and skills of the applicant and the possibility of developing them during the years of study.

- Reconsidering the academic plans related to specializations and the tourism sector to contain an evaluation of the curricula of languages and field training. This is done provided that the subjects of language take $50 \%$ of the total subjects of the specialization.

- Focusing on the medium university education in the community colleges that prepare medium labor which in turn fills the gap in the medium practical divisions of the tourist activities that attract expatriate labor.

- Evaluating the outputs of hospitality and training colleges and assessing their curricula, techniques, and efficiency in supporting the Jordanian tourist market with qualified and trained labor.

- Investigating the reality of the vocational training corporation outputs; specifying the specialization which is able to meet its requirements; and determining the tourist activities and division that those outputs are able to fulfill.

- Developing the legislations related to employment criteria, salaries, and the wages of those working in the public and private tourist sectors in appropriation with living requirements.

- $\quad$ Reconsidering the legislations concerned with investment regarding the employment of expatriate labor to determine a certain ratio of the expatriate labor in the tourist sector at specific administrative positions.

- Reconsidering the legislations of the expatriate labor in order to make the tourist sector, as a first phase, a restricted sector for expatriate labor. Then, making the tourist sector to become a closed sector gradually for the expatriate labor according to the tourist activity.

- Reconsidering the fees of the expatriate labor permits in order to increase those fees. This is done by taking into consideration the three dimensional income in the tourist sector in addition to 
stipulating specific conditions and qualifications for the expatriate labor in the tourist sector so as to minimize it.

\section{References:}

Abdel Baset Athamneh (2011). The Productivity of Jordanian Labor and Guest Labor An Econometric Analysis (1973-2009), Faculty of Economics and Administrative Sciences, Yarmouk University.

Aekl Mohammed \& Shakhatreh Hussain (1995). Bring expats Jordanian labor study within the project of promoting employment and manpower policies funded by UNDP and implemented by the ILO with the Ministry of Planning, the Ministry of Planning, Amman, Jordan

Al-Etoum (2003). The effect of substitution of expatriate labor Jordanian labor on the reality of the problem of unemployment in the Jordanian economy (Unpublished MA Thesis) University of Jordan, Jordan.

Al Jumaily (2010). Human Resources Management in tourism and Hotel Intuition.

Moutaseem for Publishing, Amman-Jordan.

Ashley \& Roe (2002). Making tourism work for the poor, Strategies and challenges in southern Africa, Development Southern Africa, 19(1), 61-82.

Dunning \& Lundan (2008). "Multinational enterprises and the global economy" , Cheltenham: Edward Elgar.

Farouq Al Azzam, Qusay Qahtan Khaleefah, \& Omar A Jawabreh (2012). Replacing Foreign Staff with Skilled Jordanian Staff in the Hospitality Industry of Four and Five Star Hotels at Aqaba City, Jordan, Archives Des Sciences.

Osama Adnan Alffendi \& Alaa Ghalib Albashaireh (2014). Foreign labor in Jordan: Analysis of reality and replacement policies, the National Center for Human Resources Development, Jordan.

Safaa Abdel Latif Mohammed bony \& Abdel Azim Suleiman (2010). Impact of Foreign Labour On Unemployment Rates In Sudan For The period 19992008, Khartoum: Sudan University of Science and Technology, School of Business Studies.

Shara et al. (1994). Demand for labor and the elasticities of substitution in the Jordanian labor market, Yarmouk Research Journal, a series of human and social sciences, 10 (3), pp. 173-218.

Te Velde \& Morrissey (2002). Foreign direct investment, skills and wage inequality in East Asia. Presented at the DESG conference.

Ministry of Tourism and Antiquities (2015). Department of Statistics and Information, the annual report for 2015. 